\title{
Theory as a 'Tool-Box': The Brno Theatralia Conference 2018
}

\author{
Dita Lánská
}

A Structural Approach to Art: Otakar Zich and the Prague Linguistic Circle Re-Considered. 8-9 June 2018, Department of Theatre Studies at Masaryk University, Brno, Czech Republic

The International symposium subtitled A Structural Approach to Art: Otakar Zich and the Prague Linguistic Circle Re-Considered was one of a series of conferences held by the Department of Theatre Studies at Masaryk University (Brno, Czech Republic) in relation to continuing research into Structuralism.

This event was specifically dedicated to the scientific work of Czech aesthetician Otakar Zich, that practically established modern Czech theatre theory. His founding writing The Aesthetics of Dramatic Art (1931) provides a connecting line between the Formalist aesthetics of the $19^{\text {th }}$ century and a Structuralist approach to theatre. In his systematic theory, Zich considered the theatre as a complex of various parts of the whole. His differentiation of the semantic technical image (the actor's figure) and the semantic visual image (the dramatic person) has also been identified as an initial impulse of semiotic thinking in Czech arts science. Zich's work is the subject of a currently ongoing project of the Department of Theatre Studies at Masaryk University, of which the main output will be an English critical edition of The Aesthetics of Dramatic Art.

The first section of symposium was dedicated to a pedagogical possibilities: how to teach semiotics. Yana Meerzon (University of Ottawa, Canada) presented in keynote lecture detailing her experience teaching theatre students. Her pedagogical activity denied conjecture about the discontinuity of theatre practice and theatre theory. In Meerzon's opinion, using the theoretical models of Prague School scholars (and related thinkers like Karel Brušák, Felix Vodička, Otakar Zich or Lubomír Doležel) develops students' creativity. In general, she understands theory as a tool-box for gripping the theatre itself and in the making of theatre. In my opinion, this was a central topic of the conference.

After Meerzon Martin Revermann (University of Toronto, Canada) made a speech stimulating vivid discussion about possible ways of teaching theatre semiotics. He invited the participants of the symposium to share their own experiences with students because his students often ask why they should use such theory, why could object not simply exist without meaning? Revermann's contribution touched the crucial item that emerged several times during the conference - the status of theory in society/theatre science and practitioners' perception of it. He called for more inclusion of theatre theory into the teaching of theatre practitioners, and for greater efforts to pass on the ability and to mediate the motivation to think theoretically in general. 
The second section of the conference opened with Tereza Turzíková (Masaryk University, Czech Republic) who reflected on possible ways of reading contemporary theatre performance. She attempted to use the Deleuzian theatre theory of post-Structuralist performance theorists to analyse the production of Czech performance theatre D'Epog, based in Brno. Turzíková's paper represented step beyond Structural theory and reminded participants of the necessity of new approaches in connection with current developments of theatre and theatrical forms in order better to comprehend it. On the contrary, Eva Šlaisová (Charles University, Czech Republic) applied structural analysis to contemporary performance art. In this case, Šlaisová demonstrated the need to update older theory and use it for new forms of art. Šlaisová described video mapping $L e$ Ballet des Ombres Heureuses (Strasbourg, 2017) through terms such as function, structure and sign and wanted to show the potency of the theories of the Prague School when applied to such material.

The last section of the first day of symposium put participants in the mood for an evening production of the concert version of parts of Zich's opera Vina [Guilt]. Brian Locke (Western Illinois University, United States of America) dealt with this opera from a musicological point of view. He described Zich as a representative of musical Modernism and argued that that's why critics disapproved of his opus. According to Locke, Vina was the first fundamentally post-tonal work in the history of Czech opera. Locke also emphasized Zich's treatment of silence in the opera.

Tereza Zálešáková (Masaryk University, Czech Republic) tried to revise Ivo Osolsobě's theory of musical theatre as a dramatic genre. Osolsobě thought about 'classic' American musical comedies of the 1960s and examined the ways in which contemporary musicals differ from them in many ways. Zálešáková asked a question: Is Osolsobě's theory applicable to the latter musical productions? She mentioned more theories suitable for this purpose, for example theory of Michael Kunze or Olaf Jubin. Pavel Drábek expressed gratitude for revisiting older theories because in his opinion it is very important to do that.

Pavel Drábek opened the second day of symposium with a keynote speech about Zich's position in theatre aesthetics. Drábek sees a combination of radical and traditionalist theories as the principal cause of Zich's scientific specificity. Zich lived in an epoch of crossing traditional and avant-garde types of theatre. Drábek also mentioned changes in theoretical physics that had influenced art theory. He perceived Zich's conception of theatre as complementary implementation of both synthetic and analytical theory, that complement each other. This approach is relational and non-normative. The relativity of this observation is, in Drábek's opinion, the avant-garde dimension of Zich's way of thinking. This was the most important thought of Drábek's lecture - the relativity of a theoretical grasp of the phenomenon at play when the object is changing as a function of the angle of sight. It is an attempt to think about it, not describe it.

Martina Musilová (Masaryk University, Brno and the Czech Academy of Performing Arts) focused on Zich's theatre background and his theoretical approach to it. Musilová mentioned the influence upon Zich of contemporary science, the state of the theatre and also the mentality of his 
generation. He belonged to the first Modernist generation; but also experienced the second wave of theatrical Modernism. Associative psychological theory had an impact on his viewing of the individual and acting, as well as the fact that he had practical experience from opera theatre.

David Drozd (Masaryk University, Brno) analysed Zich's theatre reviews and identified in them some characteristics. Drozd deduced from Zich's demands on opera production development of his concept of theatre long before publishing The Aesthetics of Dramatic Art.

Veronika Ambros (University of Toronto) made an overview of Prague School scholars that Zich had influenced in their theories like Petr Bogatyrev, Jindřich Honzl, Jan Mukařovský or Jiří Veltruský.

Herta Schmid (University of Potsdam, Germany) was seeking similarities between Zich's and Aristotle's way of thinking in her contribution: firstly, both theorists were writing about what they considered to be good drama, so their approach included the evaluation of a play; both set two actors as the minimum necessary means for drama. The third parallel was the fact that in both theories the actor is at the centre of dramatic art. In essence they played the same role in the process of cognition of other thinkers, they laid the foundations of scientific thinking for further researchers.

Bohumil Fořt (Masaryk University, Brno) discussed Zich's On Poetic Types (1918). This text is considered as the basis of Structuralist methodology. Czech aestheticians like
Oleg Sus or Jan Mukařovský referred to this paper and it is an important epistemological fulcrum in the history of Czech literary science.

Martin Bernátek (Palacký University, Olomouc and Masaryk University, Brno) and Jan Trna (Masaryk University, Brno) ended the conference with an interesting report on the manuscript of a German translation of The Aesthetics of Dramatic Art found in Zich's estate in the National Museum. Bernátek speculated about the author and initiator of the translation and the reason why it was not published although the work was complete. Trna analysed the text from a linguistic point of view and came to the conclusion that the author was probably Czech or Slovak because of the frequent using of idioms.

The symposium touched on crucial topics such as the meaning of theory in general, the position of theory in the field of theatre studies, the necessity of interdisciplinary and international collaboration and the connection between theory and practice. In my opinion there has been in recent years an essential change in perceiving theory, as this conference has articulated - it should not be a fixed, normative or intolerant description. As Pavel Drábek said, as well as writing about history we must think about theory - scientists always have this frame and determination (which affects their interpretation of the subject that they are investigating) and we too have to count on it. Theory is a tool-box for exploring more fully the phenomena that interest our minds. 